$\begin{array}{cc}\text { ACADEMIA ROMÂNĂ } & \text { Rev. Roum. Chim., } \\ \text { Revue Roumaine de Chimie } & \text { D5(11), 983-988 } \\ \text { http://web.icf.ro/rrch/ } & \text { DoI: 10.33224/rrch.2020.65.11.03 }\end{array}$

\title{
INVESTIGATION OF DYEING PROPERTIES OF DIFFERENT FABRIC SPECIES WITH CURCUMA LONGA EXTRACTS
}

\author{
Adem ONAL ${ }^{\mathrm{a},{ }^{*}}$ Kevser Ceren TOMBUL ${ }^{\mathrm{b}}$ and Sama NACHED ${ }^{\mathrm{b}}$ \\ ${ }^{a}$ Tokat Gaziosmanpasa University, Natural Dyes Application and Research Center, 60250, Tokat, Turkey \\ ${ }^{\mathrm{b}}$ Tokat Gaziosmanpaşa University, Department of Molecular Biology and Genetics, 60250 Tokat, Turkey
}

Received January 29, 2020

\begin{abstract}
The dyeing properties of different fabric species were investigated using root extract of Curcuma Longa rhizome. For this purpose, the cotton and wool fabrics were dyed using the root extract of Curcuma Longa by pre-mordanting, together-mordanting and last-mordanting methods with copper sulfate $\left(\mathrm{CuSO}_{4}\right)$, ferrous sulfate $\left(\mathrm{FeSO}_{4}\right)$ and aluminum potassium sulfate $\left(\mathrm{AIK}\left(\mathrm{SO}_{4}\right)_{2}\right.$ at medium $\mathrm{pH}$. The color codes were determined with Pantone Color Quide, and $\mathrm{K} / \mathrm{S}$ and $L^{*} a^{*}$ $b^{*}$ values were detected with color measurement spectrophotometer, and also washing-, crocking-fastness levels were evaluated using gray scale.
\end{abstract}

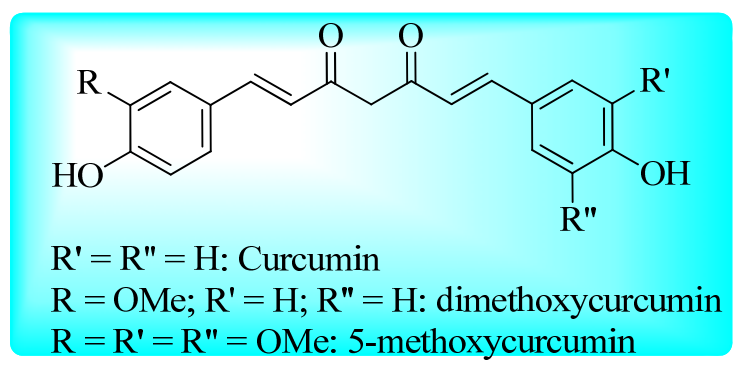

\section{INTRODUCTION}

Natural dyes are widely used in colouring of food substrate, natural fibres including wool, silk, cotton and leather from ancient times. ${ }^{1}$ The usage of natural dyes in textile dyeing is increasing day by day because of the worldwide environmental consciousness. ${ }^{2}$ In addition, they are non- allergic, non-toxic to human body. ${ }^{3}$ Dyeing of fibres with the extract of the plant is generally carried out the parts of the plant such as bark, flowers, leaves and seed.

Natural products are used in many areas of the industry due to their biological activities and versatile application areas. ${ }^{4,5}$ Turmeric is a perennial and tuberous herbaceous plant with yellow flowers and large leaves belonging to the ginger family. The active components in turmeric are curcuminoids which mainly consist of curcumin (Fig. 1) followed by dimethoxy curcumin and bis-dimethoxy curcumin. Curcumin constitutes up to $15 \%$ of dry weight of Curcuma Longa. ${ }^{6}$ The chemical structure of curcumin is 1,7-bis[4-hydroxy-3-methoxphenyl]-1,6heptadiene-3,5-dione which is called C. I. Natural Yellow 3 and it exhibits a wide variety of biological activities.

According to the literature surveys, the dyestuff in Curcuma Longa is curcumin. ${ }^{6}$

Ghoreishlan et al. have investigated the antibacterial properties and color fastness of silk fabric with turmeric extract. ${ }^{6}$ Erten Nagehan examined the possible neuroprotective effect of curcumin treatment in diabetic neuropathy on rats. ${ }^{7}$ Karaman and Koseler have reported turmeric has been shown to have strong antioxidant and antiinflammatory effects. ${ }^{8}$ Wei-ni et al. have obtained high rubbing fastness in the dyeing of Soybean leaf having antimicrobial properties dyeings. ${ }^{9}$ Askar et al. have detected the in-vitro antibacterial activities and minimal inhiboritiy concentration of Curcuma Longa. ${ }^{10}$ 


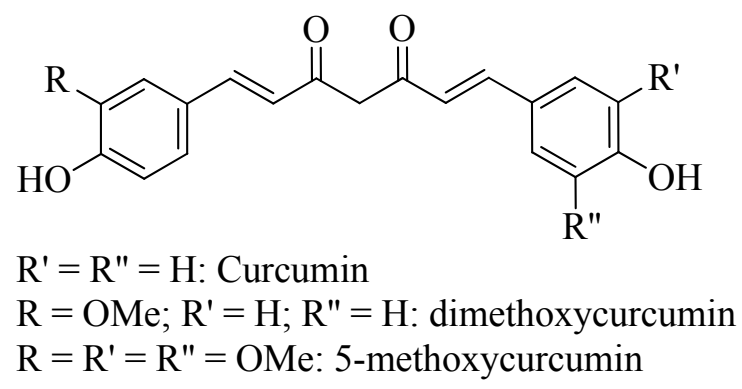

Fig. 1 - Structure of Curcumin.

In this study, the dyeing properties of difference fabrics species were investigated using Curcuma Longa extract. For this aim, the cotton and the wool fabrics were dyed using pre-mordanting, together-mordanting and last-mordanring methods with copper sulfate $\left(\mathrm{CuSO}_{4}\right)$, ferrous sulfate $\left(\mathrm{FeSO}_{4}\right)$ and aluminium potassium sulfate $\operatorname{AIK}\left(\mathrm{SO}_{4}\right)_{2}$ were used as mordant. All dyeings were carried out at medium $\mathrm{pH}$.

\section{RESULTS}

\section{Proposed Dyeing mechanism}

Metal complex formation has been an outstanding property of textile dyeing from ancient times. This procedure increases the fastness of fabric provides variety of colors. Al (III) and $\mathrm{Fe}$ (II) ions have a coordination number of six and they are able to make complexes in the octahedral configuration. So, in the proposed mechanisms which are given in Figure 1, the unoccupied sites of the metal ions may be occupied with $\mathrm{H}_{2} \mathrm{O}$ molecules, oxochrome groups of the dyestuff or free amino and carboxyl groups of wool fabric. Proposed dyeing mechanism of wool and cotton fabric with the extract of Curcuma Longa are given in Figures 1 and 2.

Because of the cotton has cellulosic structure, coordine covalent bonding occurs between $\mathrm{CH}_{2} \mathrm{O}$ - groups of cellulose and metal cation. The suggested mechanism is given Figure3.

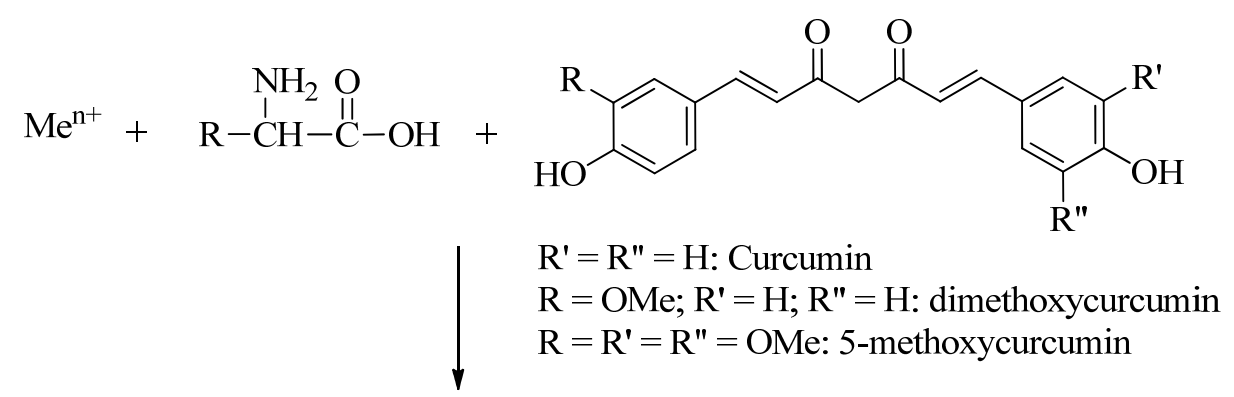

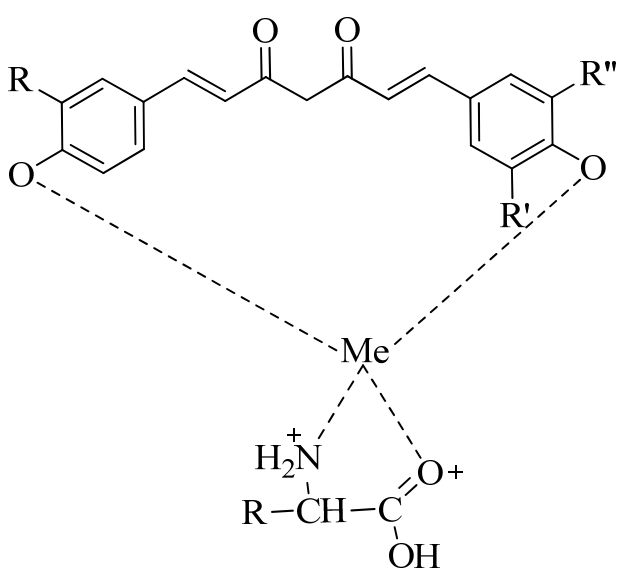

Fig. 2 - The proposed dyeing mechanism of wool fabric with Curcuma longa extract $\left(\mathrm{Mn}^{+}: \mathrm{Cu}^{2+}, \mathrm{Fe}^{2+}, \mathrm{Al}^{3+}\right)$. 

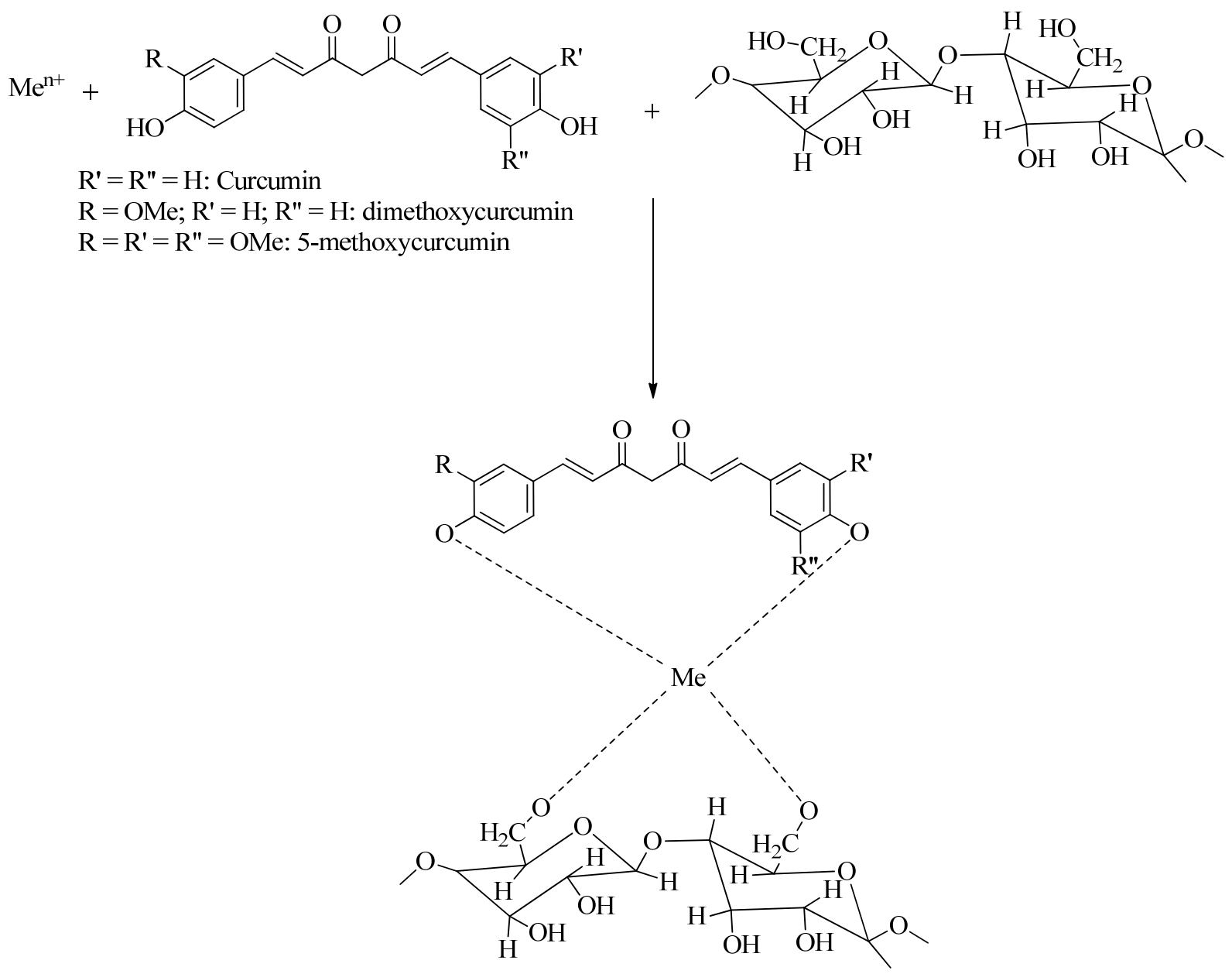

Fig. 3 - The dyeing proposed mechanism of cotton fabric with Curcuma Longa extracts.

\section{EXPERIMENTAL}

\section{Natural dye extraction and mordanting}

Light, rubbing and washing fastness properties and color codes of dyed cotton fabrics are given in Table 1. Curcuma Longa used as a natural dye source which was purchased from the Tokat region (Turkey). $50 \mathrm{~g}$ of Curcuma Longa powder was refluxed on soxhlet apparatus using distilled water until colorless. This procedure was applied until 5 liters of color extracts, and finally all extracts were collected. Ferrous sulfate, copper sulfate and aluminium potassium sulfate were used as mordants; the pre-mordanting, together mordanting and last mordanting were used as mordanting methods.

\section{Reagens and equipment}

All chemicals and mordant salts $\mathrm{FeSO}_{4} \cdot 7 \mathrm{H}_{2} \mathrm{O}$, $\mathrm{AlK}\left(\mathrm{SO}_{4}\right)_{2} \cdot 12 \mathrm{H}_{2} \mathrm{O}$ and $\mathrm{CuSO}_{4} \cdot 5 \mathrm{H}_{2} \mathrm{O}$ were puschased from Merck. Curcuma Longa was supplied from Tokat-Turkey. Degummed cotton and wool fabric (plain woven, $190 \mathrm{~g} / \mathrm{m}^{2}$ $230 \mathrm{~g} / \mathrm{m}^{2}$ ) were provided from Toga Textile Ltd., TokatTurkey. Distilled water was used for all steps. Extraction was performed by using soxhlet apparatus. Color codes were determined by Pantone Color Guide. The wash-, crock- (wet, dry) and light- fastnesses of all dyed samples were established according to ISO 105-C06 and to CIS. Fastness values were determined by Atlas weather-ometer, a Launder-ometer and a 255 model crock-meter, respectively. ${ }^{11}$

\section{Dyeing procedure}

All dyeing procedure were applied according to the literature. $^{12,13}$

\section{Pre-mordanting method}

The fabric $(5 \mathrm{~g})$ was heated in $0.1 \mathrm{M}$ mordant solution $(100 \mathrm{~mL})$ for $1 \mathrm{~h}$ at $70{ }^{\circ} \mathrm{C}$. After cooling of sample, it was rinsed with distilled water and put into dye-bath solution $(100 \mathrm{~mL})$. It was heated at $70{ }^{\circ} \mathrm{C}$ for $1 \mathrm{~h}$. the dyed material was rinsed with distilled water and dried. ${ }^{12}$

\section{Together mordanting}

Mordant (in solid state which equivalent to $0.1 \mathrm{M}$ mordant solution), dyestuff solution and fabric were put into the flask and heated at $70{ }^{\circ} \mathrm{C}$ for $1 \mathrm{~h}$. After cooling, it was rinsed and dried. $^{14}$

\section{Last mordanting}

On the contrary to pre- mordanting method, the fabric $(5 \mathrm{~g})$ was first treated with dyestuff solution for $1 \mathrm{~h}$ at $70^{\circ} \mathrm{C}$. After cooling, it was rinsed with distilled water and put into $0.1 \mathrm{M}$ mordant solution $(100 \mathrm{~mL})$ and heated for $1 \mathrm{~h}$ at $70{ }^{\circ} \mathrm{C}$. Finally, the dyed material was rinsed with distilled water and dried. ${ }^{14}$ 
Table 1

Fastness values and color codes of dyed cotton samples

\begin{tabular}{|c|c|c|c|c|c|c|}
\hline Method & Mordant & pH & $\begin{array}{r}\text { Light } \\
\text { fastness }^{b}\end{array}$ & $\begin{array}{r}\text { Wash } \\
\text { fastnes }\end{array}$ & $\begin{array}{c}\text { Rubb } \\
\text { fastness } \\
\text { (wet/dry) }\end{array}$ & $\begin{array}{r}\text { Color code } \\
\text { (Pantone) }\end{array}$ \\
\hline $\mathrm{T} 1$ & M1 & 4.65 & 4 & $4 / 5$ & $5 / 5$ & $012 \mathrm{CS}$ \\
\hline $\mathrm{T} 2$ & M1 & 4.65 & 4 & $5 / 5$ & $4 / 5-5$ & $116 \mathrm{CS}$ \\
\hline $\mathrm{T} 3$ & M1 & 4.65 & $4 / 5$ & 5 & $4 / 5-5$ & $1225 \mathrm{CS}$ \\
\hline $\mathrm{T} 1$ & M2 & 6.05 & $5 / 6$ & $4 / 5$ & $4 / 5-4 / 5$ & $1230 \mathrm{CS}$ \\
\hline $\mathrm{T} 2$ & M2 & 5.05 & 5 & $4 / 5$ & $5 / 5$ & $1365 \mathrm{CS}$ \\
\hline $\mathrm{T} 3$ & M2 & 5.20 & $6 / 7$ & 5 & $4 / 5-5$ & $1206 \mathrm{CS}$ \\
\hline $\mathrm{T} 1$ & M3 & 5.60 & $3 / 4$ & $3 / 4$ & $5 / 5$ & $1205 \mathrm{CS}$ \\
\hline $\mathrm{T} 2$ & M3 & 5.75 & $3 / 4$ & 4 & $5 / 5$ & $1215 \mathrm{CS}$ \\
\hline \multirow[t]{2}{*}{$\mathrm{T} 3$} & M3 & 5.35 & 3 & 4 & $5 / 5$ & $0205 \mathrm{CS}$ \\
\hline & Unmordant. & 4.01 & 3 & 3 & $3 / 4$ & 1345 \\
\hline
\end{tabular}

M1: $\mathrm{FeSO}_{4} \mathrm{M} 2: \mathrm{Cu} \mathrm{SO}_{4} \mathrm{M} 3$ : Alum, T1:Pre- mord. T2:Together mord. T3: Last mord.

${ }^{\mathrm{a}}$ Wash fastness $1=$ poor, $2=$ moderate, $3=$ fairly good, $4=\operatorname{good}, 5=$ very good, ${ }^{\mathrm{b}}$ Light fastness $1=$ very poor, $2=$ poor, $3=$ mogerdate, $4=$ fairly good, $5=\operatorname{good}, 6=$ very good, $7=$ excellent, $8=$ outstanding and ${ }^{c}$ rub fastness $1=$ poor, $2=$ moderate, $3=$ fairly good, 5 = very good.

Table 2

Fastness values and color codes of dyed woolen fabrics

\begin{tabular}{c|c|c|c|c|c|c}
\hline Method & Mordant & $\mathbf{p H}$ & $\begin{array}{c}\text { Light } \\
\text { fastnes }\end{array}$ & $\begin{array}{c}\text { Wash } \\
\text { fastness }\end{array}$ & $\begin{array}{c}\text { Rubbing } \\
\text { fastness } \\
\text { (wet/dry) }\end{array}$ & $\begin{array}{c}\text { Color code } \\
\text { (Pantone) }\end{array}$ \\
\hline T1 & M1 & 4.65 & 4 & 5 & $5 / 5$ & $4502-\mathrm{CS}$ \\
T2 & M1 & 4.65 & $4 / 5$ & 5 & $5 / 5$ & $7508 \mathrm{CS}$ \\
T3 & M1 & 4.65 & $4 / 5$ & 4 & $5 / 5$ & $4675 \mathrm{CS}$ \\
T1 & M2 & 6.05 & $5 / 6$ & 5 & $4 / 5$ & $458 \mathrm{CS}$ \\
T2 & M2 & 5.20 & 5 & 5 & $5 / 5$ & $607 \mathrm{CS}$ \\
T3 & M2 & 5.60 & $5 / 6$ & 5 & $5 / 5$ & $4665 \mathrm{CS}$ \\
T1 & M3 & 5.60 & $3 / 4$ & 5 & $5 / 5$ & $7501 \mathrm{CS}$ \\
T2 & M3 & 5.75 & $3 / 4$ & 5 & $3 / 4$ & $7402-\mathrm{CS}$ \\
T3 & M3 & 5.35 & $3 / 4$ & $4 / 5$ & $5 / 5$ & $7401 \mathrm{CS}$ \\
\hline
\end{tabular}

M1: $\mathrm{FeSO}_{4} \mathrm{M} 2: \mathrm{CuSO}_{4} \mathrm{M} 3$ : Alum, T1:Pre- mord. T2:Together mord. T3: Last mord.

Table 1 presents washing, light and rubbing color fastness properties of the mordanted dyed cotton fabrics. It can be concluded that copper and ferrous pretreatment could increase light fastness of the samples, whereas the pre-treated samples with alum possessed the lowest light fastness. It may explicable stability of the complex molecule formed between mordant, dyestuff and fabric. Other fastnesses are close to each other for each three mordants.

Fastness values and color codes for dyed woolen fabrics have been presented in Table 2 . 
Table 2 presents washing, light and rubbing color fastness properties of the mordanted- dyed wool fabrics. It may be observed that the wash fastness values are low in dyeings with woolen fabrics for Alum for pre- and together mordanting and other fastnesses are high. However, all fastnesses are close to each other for copper and ferrous.

\section{Determination of color performance}

The spectral reflectance measurements of the naturally dyed fabrics were determined using a Konica Minolta 3600d (Japan) spectrophotometer.
Color strength was expressed as $\mathrm{K} / \mathrm{S}$ values of the dyed samples using the Kubelka-Munk equation:

$$
K / S=(1-R)^{2} / 2 R
$$

where $\mathrm{K}$ is the absorption coefficient, $\mathrm{R}$ is the reflectance of the dyed sample and $\mathrm{S}$ is the scattering coefficient. $L^{*} a^{*} b^{*}$ and $\mathrm{K} / \mathrm{S}$ values of cotton and woolen samples.

As seen Table 3, it was obtained in different shades of color intensity for cotton fabrics. Yellow color tones were obtained, generally. The value of $a^{*}$ is negative and the color has shifted to brown with copper sulfate in pre-mordanting. The highest $\mathrm{K} / \mathrm{S}=12.60$.

Table 3

$L * a * b *$ and $\mathrm{K} / \mathrm{S}$ values of cotton and woolen samples

\begin{tabular}{|c|c|c|c|c|c|}
\hline Fabric & Mordant & $L^{*}$ & $a^{*}$ & $b^{*}$ & $\mathbf{K} / \mathbf{S}$ \\
\hline Cotton & $\mathrm{FeSO}_{4}$ & 70.10 & 6.21 & 47.68 & 8.82 \\
\hline$"$ & $\mathrm{FeSO}_{4}$ & 67.30 & 7.01 & 49.77 & 12.60 \\
\hline$"$ & $\mathrm{FeSO}_{4}$ & 66.75 & 6.33 & 50.41 & 8.14 \\
\hline$"$ & $\mathrm{CuSO}_{4}$ & 73.06 & -5.01 & 49.42 & 3.39 \\
\hline$"$ & $\mathrm{CuSO}_{4}$ & 72.41 & 2.08 & 48.27 & 6.79 \\
\hline$"$ & $\mathrm{CuSO}_{4}$ & 70.95 & 3.50 & 49.52 & 2.11 \\
\hline$"$ & $\mathrm{AlK}\left(\mathrm{SO}_{4}\right)_{2}$ & 87.22 & 0.46 & 57.12 & 4.51 \\
\hline$"$ & $\mathrm{AlK}\left(\mathrm{SO}_{4}\right)_{2}$ & 75.27 & 2.17 & 55.01 & 3.10 \\
\hline$"$ & $\mathrm{AlK}\left(\mathrm{SO}_{4}\right)_{2}$ & 70.28 & 0.86 & 56.01 & 1.80 \\
\hline Wool & $\mathrm{FeSO}_{4}$ & 63.27 & 5.25 & 50.02 & 2.55 \\
\hline$"$ & $\mathrm{FeSO}_{4}$ & 65.91 & 5.45 & 49.12 & 2.14 \\
\hline$"$ & $\mathrm{FeSO}_{4}$ & 59.92 & 6.02 & 50.44 & 5.50 \\
\hline$"$ & $\mathrm{CuSO}_{4}$ & 67.66 & 2.51 & 49.22 & 2.30 \\
\hline$"$ & $\mathrm{CuSO}_{4}$ & 55.05 & 2.08 & 50.98 & 5.90 \\
\hline$"$ & $\mathrm{CuSO}_{4}$ & 71.30 & -0.01 & 47.25 & 1.85 \\
\hline$"$ & $\mathrm{AlK}\left(\mathrm{SO}_{4}\right)_{2}$ & 72.78 & 1.18 & 55.09 & 2.22 \\
\hline$"$ & $\mathrm{AlK}\left(\mathrm{SO}_{4}\right)_{2}$ & 72.68 & 0.54 & 61.10 & 3.45 \\
\hline$"$ & $\mathrm{AlK}\left(\mathrm{SO}_{4}\right)_{2}$ & 73.84 & 0.7376 & 64.98 & 1.56 \\
\hline $\begin{array}{l}\text { Unmordant- } \\
\text { cotton }\end{array}$ & - & 52.79 & 1.30 & 45.01 & 1.25 \\
\hline $\begin{array}{l}\text { Unmordant- } \\
\text { wool }\end{array}$ & - & 57.60 & 1.95 & 6.05 & 2.19 \\
\hline
\end{tabular}


According to the Table 3, it was obtained in different shades of color intensity for woolen fabrics and pale brown color tones were usually obtained. The value of $a^{*}$ is negative for copper sulfate in pre-mordanting, and also the color has shifted to brown with ferrous sulfate in together- mordanting. The highest K/S (5.90) value was obtained with copper sulfate in the together-mordanting.

\section{CONCLUSIONS}

In this research, the Curcuma Longa extract was used for dyeing of wool and cotton fabrics. Natural dye solution was extracted and applied to the selected fabrics using pre-, together-, and lastmordanting techniques. Yellow, pale yellow, bright yellow, orange, pale brown color tones were obtained. Except of Alum, all fastnesses are good. Light fastness for alum is lower than other mordants. It can be concluded that copper and ferrous pre-treatment could increase light fastness of the samples, whereas the prereated samples with alum possessed the lowest light fastness. We can say thatit could be considered as asign of possible coordinative metal bridging between the dye and the fiber in the pretreated samples. The wash and light fastness properties are found to be enhanced when mordanting was done. As a result, the dyeing with the extract of Curcuma Longa can be apromising, simple and practical method for imparting color on the cotton and wool fabrics.

\section{REFERENCES}

1. A. K. Samanta and P. Agarwal, Indian J. Fibre \& Text. Res., 2009, 34, 384-399.

2. S. Y. Kamat and D. V. Alat, The Indian Text. J., 1990, 3, 66-70.

3. A. Moiz, M. A. Ahmed, N. Kausar, K. Ahmed and M. Sohail, J. Saudi Chem. Soc., 2010, 14, 69-76.

4. O. Özbek, Y. Budak, C. Berkel, C. Özyigit, Y. Yanar, Int. J. Agric. Environ. Food Sci., 2020, 4(4), 476-482.

5. M. B. Gürdere, A. Aydin, B. Yencilek, F. Ertürk, O. Özbek, S. Erkan, Y. Budak, M. Ceylan, Chemistry Biodivers., 2020, 17, e2000139.

6. S. M. Ghoreishian, L.Maleknia, H. Mirzapour and M. Norouzi, Fibers and Polym., 2013, 14, 201-207.

7. N. Erten, connection: http://hdl.handle.net/1160773267, 2018.

8. B. E. Karaman and E. Köseler, J. Healt. Sci., 2017, 2, 96112.

9. J. Wei-ni, L. Peng and Z. Rui-ping, "Dyeing of soybean protein leaf with curcumin", Textile and Fashion School, Nantong university, Nantang, 2012.

10. S. Askar and S. N. Deveboynu, Eurasian J. Health Sci., 2018, 1, 1-6.

11. M. Tutak and H. Benli, Asian J. Chem., 2011, 23, 566568.

12. A. Onal, Turk. J. Chem., 1996, 20, 194-203.

13. A. Önal, O. Özbek and S. Nached, J. Turk. Chem. Soc., Sect. A: Chem., 2020, 7, 821-826.

14. A. Onal, "Natural Dyestuffs", Gaziosmanpaşa University, Faculty of Art and Sciences, Tokat-Turkey 2000. 